\title{
Bio-aviation fuel via catalytic hydrocracking of waste cooking oils
}

\author{
R. El-Araby*, E. Abdelkader, G. El Diwani and S. I. Hawash
}

\begin{abstract}
Background: Biomass fuels (bio-jet fuel) have recently attracted considerable attention as alternatives to conventional jet fuel. They have become the focus of aircraft manufacturers, engines, oil companies, governments and researchers alike. This study is concerned with the production of biojet fuel using waste cooking oil (WCO). Batch reactor is used for running the experimental study. The catalytic cracking products are investigated by GC mass spectra. Final products from different reaction conditions are subjected to fractional distillation. The (Bio kerosene) fraction was compared with the conventional jet A-1 and showed that it met the basic jet fuel specifications. Optimum reaction conditions are obtained at $\left(450^{\circ} \mathrm{C}\right)$, pressure of $(120 \mathrm{bars})$, catalyst dose $(2.5 \% \mathrm{~W} / \mathrm{v})$, reaction time $(60 \mathrm{~min})$ and hydrogen pressure 4 atmosphere. The aim of this study is to produce bio aviation fuel according to specifications and with a low freezing point from waste cooking oil in one step using a laboratory prepared catalyst and with a low percentage of hydrogen to complete the process of cracking and deoxygenation in one reactor, which is naturally reflected positively on the price of the final product of bio aviation fuel.

Results: The results indicated that the product obtained from WCO shows promising potential bio aviation fuels, having a low freezing point $\left(-55^{\circ} \mathrm{C}\right)$ and that all bio kerosene's specifications obtained at these conditions follow the international standard specifications of aviation turbine fuel.

Conclusion: Biojet fuel obtained from WCO has fairly acceptable physico-chemical properties compared to those of petroleum-based fuel. Adjustment of the hydro catalytic cracking reaction conditions was used to control quantities and characteristics of produced bio aviation fuel. Taking into consideration the economic evaluation WCO is preferable as raw material for bio aviation fuel production due to its low cost and its contribution in environmental pollution abatement. Blend of $5 \%$ bio aviation with jet A-1 (by volume) can be used in the engine without any modifications and a successful test of blended aviation fuel with 10\% bio aviation has been achieved on Jet-Cat 80/120 engine.
\end{abstract}

Keywords: Bio aviation fuel, Hydrocracking, Catalytic, Waste cooking oils

\section{Background}

Aviation sector is one of the strongest growing transport sectors. Global airline operations consumed around 1.5 billion barrels of Jet A-1 fuel. Jet fuel consumption of 705 million metric tons (Mt) generates significant greenhouse gas emissions, accounting for about $2 \%$ of global $\mathrm{CO}_{2}$ emissions each year (www.climatesolutions.org/progr ams/aviation-biofuels-initiative). For Egypt from 1980 to

\footnotetext{
*Correspondence: rehamelaraby@hotmail.com

Chemical Engineering and Pilot Plant Department, National Research Center, Cairo, Egypt
}

2016, the average consumption value during that period was 19.32 thousand barrels per day, with a minimum of 7.29 thousand barrels per day in year 1980 and a maximum of 38.11 thousand barrels per day in 2010 (https:// www.theglobaleconomy.com/Egypt/jet_fuel_consumptio $\mathrm{n} /$ ). Awareness of greenhouse gas emissions and climate change push researchers and airlines sector to develop renewable jet fuel alternatives.

Biomass fuels (bio-jet fuel) have recently attracted considerable attention as alternatives to conventional jet fuel. They have become the focus of aircraft manufacturers, engines, oil companies, governments and 
researchers alike. IATA identified biofuels as the most promising strategies to reduce carbon dioxide emissions from the aviation sector in the foreseeable future (Yang et al. 2019).

The high dependence of the bio-jet production cost would be on the following parameters: (1) feedstock's composition and cost, (2) process design, (3) product yield or conversion efficiency, (4) co-product's valorization; and (5) energy conservation. Hence, decreasing the production cost of bio-jet fuel depends on significant hard work in all areas, including enhancements in the areas of feedstock productivity, the extracted yield of oil or sugar yield from the crops, process conservation energy, and balance between jet fuel product and coproducts added value (Wang and Tao 2016).

Derived jet fuels from renewable feedstock can reduce the dependency of the aviation industry on one single energy source. Also this can decrease the petroleum prices, and essentially lowering greenhouse gas (GHG) emissions. The use of aviation biofuels could reduce greenhouse gas emissions in the life cycle of aviation by a range of $68.1 \%$ in 2050 (Staplesa et al. 2018; Blakeley 2012; Tao et al. 2017).

Investigators from different academia and organizations (the oil-refining industry, the aviation industry, government, bio fuel companies, agricultural organizations), tried to develop new commercially practicable and sustainable processes that produce renewable low cost jet fuels with low greenhouse gas emissions. Produced jet fuels must meet (ASTM) international standards and can be a $100 \%$ drop-in replacement for the current petroleum jet fuel. The emissions after combustion and engine tests show up the benefits of running the aero plane with biojet fuels. Technologies for producing renewable jet fuels from different pathways containing alcohols-to-jet, oilto-jet, syngas-to-jet, and sugar-to-jet, are studied. The main challenges for each technology pathway, including feedstock availability, process conceptual design and economics, life-cycle assessment of greenhouse gas emissions, and commercial willingness, are discussed (Wang et al. 2016).

Several types of feed stocks for bio aviation fuel production are listed as (a) oil-based feedstocks, such as vegetable oils, waste oils, algal oils, and pyrolysis oils; (b) solid-based feedstocks, such as lignocellulosic biomass (including wood products, forestry waste, and agricultural residue) and organic portion of municipal waste or (c) gas-based feedstocks, such as biogas and syngas (ICCT 2019).

Using Camelina, jatropha and algae, as raw materials for Jet fuel production reduce the fuel's carbon foot print by $80 \%$ relative to jet fuel without competing for food sources (Bailis and Bake 2010).
Basically, kerosene is a straight-run distillate of petroleum fraction with boiling temperature ranging from 205 to $260^{\circ} \mathrm{C}$. Increasing jet fuel production decreases obviously the production of other products (Sun 2012).

Also safety and security of supply criteria change and developed the specifications of aviation kerosene (Pires et al. 2018; Corporan et al. 2011; Hileman and Stratton 2014). Strategy of both environmentally and economically feasibility of bio fuel production is related to the development of conversion technologies and feed stock resources so that the cost-competitive production of bio fuels is compatible with the use of sustainable low cost, and diverse feed stocks (Sathaye et al. 2011; Skreiberg et al. 2013).

Most contaminants that result in bio oil yields can be traced back to the feedstock, such as residual solids (char), alkali metals, and high water content (Zacher et al. 2014a).

Common technologies used is catalytic hydride oxygenation at high pressure (Mante et al. 2017) which generates a hydrocarbon liquid suitable for co-processing in a petroleum refinery or blending into finished fuel (Talmadge et al. 2014). To achieve IATA goals, higher blending rates may eventually be required. In fact, this product may not be available everywhere during the growing period. The ability to mix higher ratios in some locations can help achieve the establishment objectives, taking into account the local availability of the product (Chuck and Donnelly 2014). The first task of the High Biofuel Blends in Aviation (HBBA) study was to establish the relevant range of properties of conventional kerosene properties, and to identify sources for the supply of suitable samples (Prussi et al. 2019). The target set by the European Union Flightpath for the aviation sector focuses on all methods of production, but in particular, takes into account artificial paraffin or biologically derived biomass. Aviation biofuels must be fully compatible and can be combined with standard fossil fuels (such as Jet-A fuel). These fuels should also be tested and approved before commercial use, and emissions are verified. In addition, production and use should not only be developed and verified, but also the entire transport and distribution chain (Chairamonti 2019).

Conventional biofuels cannot be mixed even in very few percentages with fossil kerosene, as the fuel standards are too strict for aircraft engines. This also applies to distilled fractions of conventional biofuels (Chuck and Donnelly 2014).

The first track relies on vegetable oils and fats, and therefore on raw materials such as oilseeds or fat-rich algae, residues such as cooking oil used or animal fat, or even common products such as tall oil from the papermaking industry (Chuck and Donnelly 2014; Prussi et al. 
2019). Esterification is not a vital option for the production of aviation fuel: the so-called "biodiesel", is a mixture of fatty acid methyl esters (FAME) to be used as a low component (5-7\%) in the land transport mix. On the contrary, hydrogen treatment of fats can be applied to the production of jet fuel, as has already been done by many companies (such as Neste Oil, Petrobras, ENI/UOP, etc.) to obtain high-quality biomass-derived fuel, compared with FAME (Chairamonti 2019).

It is clear that if biodiesel is to be used for aviation then it will have to contain short-chain esters rather than longchain polyunsaturated. While hydrogen-treated triglycerides are accepted as synthetic aviation fuels, a number of studies have shown biodiesel, alkyl esters of fatty acids produced by the glyceride transformation process, to be a suitable fuel for gas turbine engines. Biodiesel typically contains straight-chain fatty acid esters ranging from 16 to 18 carbon atoms that can contain 3 double bonds. Biodiesel is suitable for aviation if composed solely of short chain saturates (Chuck and Donnelly 2014; Wang et al. 2016). However, the melting points of long-chain saturated and unsaturated esters are too high to be suitable for flight. Reducing the length of the chain or increasing the level of saturation significantly reduces the freezing point (Wahyudi 2018; Holladay 2015a; Gawron and Białecki 2018).

Numerous literatures have examined the effect of hydro treating process on bio-oil characteristics (Zacher et al. 2014b; Howe et al. 2015). The produced hydrocarbon via zinc aluminate as catalyst was mainly branched alkanes and cycloalkanes with a maximum yield $\approx 89 \%$ after upgrading and distillation processes (Hawash et al. 2017). Overall, thermo- chemical conversion is an important route for the production of biojet fuel using vegetable oils (Xu et al. 2016).

The present investigation is undertaken to study the effect of change of operating conditions in the hydro thermal catalytic cracking process for converting waste cooking oils to bio aviation fuel through the determination of different parameters representing the experimental results based on the rate of depression in freezing point of the produced bio kerosene with different reaction conditions and the test proved that the obtained thrust of using $10 \%$ blend of the produced bio aviation fuel is in a good agreement with jet A-1 specifications.

\section{Methods}

Materials

- (WCO) feed stock was collected from local Egyptian fast food restaurants.

- Nano (Zinc Aluminate) catalyst was freshly prepared through the present study.

\section{Raw materials preparation}

Preparation of waste cooking oil

The WCO was filtered to remove any solid impurities prior to the analysis.

\section{Preparation of catalyst $\left(\mathrm{Zn} \mathrm{Al}_{2} \mathrm{O}_{4}\right)$ nano particles}

The used Zinc aluminate as a catalyst was prepared by co-precipitation method using $48 \mathrm{~g} \mathrm{H}_{2} \mathrm{O}$, zinc nitrate $\mathrm{Zn}\left(\mathrm{NO}_{3}\right)_{2} \cdot 6 \mathrm{H}_{2} \mathrm{O}$ (96\% purity) and $120 \mathrm{~g}$ aluminum nitrate $\mathrm{Al}\left(\mathrm{NO}_{3}\right)_{3} \cdot 9 \mathrm{H}_{2} \mathrm{O}$ (98\% purity) (Diwani et al. 2009; Battiston et al. 2014), LOBA CHEMI company. $\left(\mathrm{ZnAl}_{2} \mathrm{O}_{4}\right)$ nano particles were investigated by using transmission electron microscope (TEM) which operates on the same basic principles as the light microscope but uses electrons instead of light, small amount of powder was dispersed in ethanol using an ultrasonic bath for $30 \mathrm{~min}$. Then few drops were placed onto a carbon coated cupper grid. Specific surface area was calculated by BET method using $\mathrm{N}_{2}$ adsorption experiments.

BET surface area analyzers determine the total surface area of a solid by suspending a powdered analyte in an inert gaseous bath and measuring the adsorption of gas molecules to the surface and its porous structures. This can be measured volumetrically or via a continuous flow.

\section{Preparation of thermal hydro-catalytic cracking process}

The experimental work was carried on floor-stand reactor under pressure (Parr reactor) with $400 \mathrm{ml}$. volume. The reactor includes stainless steel vessel, pressure gauge and a heating jacket. The temperature inside the reactor was controlled by proportional integral derivative panel (PID).

The reactor vessel was charged with oil $(100 \mathrm{ml})$ and $(2.5 \% \mathrm{w} / \mathrm{v})$ of $\mathrm{ZnAl}_{2} \mathrm{O}_{4}$ catalyst. Applied process parameters were varied: the reaction temperature from 400 to $450{ }^{\circ} \mathrm{C}$, starting hydrogen pressure of $4 \mathrm{~atm}$ then the pressure increased with heat and time to reach a range of (59-130 bass), and the reaction time from 20 to $60 \mathrm{~min}$. Operating conditions of different experiments are shown in Table 1 and the process flowchart is illustrated in Fig. 1. the reaction operating conditions were changed as follows:

- Time from 20 to $60 \mathrm{~min}$.

- Temperature from 350 to $450^{\circ} \mathrm{C}$.

- Hydrogen pressure of 4 bars.

\section{Preparation of fractional distillation steps}

Scaling-up of the thermal catalytic cracking reaction is achieved in a reactor of 1 gallon (3.7 L), at the optimum operating conditions obtained in the $400 \mathrm{ml}$ batch reactor. Product of this run is fractionally distilled at 
Table 1 Experimental conditions for batch biojet fuel preparation (catalyst: 2.5 vol\%)

\begin{tabular}{llll}
\hline Run no. & Temperature $\left({ }^{\circ} \mathbf{C}\right)$ & Time $(\min )$ & $\begin{array}{l}\text { Final } \\
\text { pressure } \\
(\text { bar })\end{array}$ \\
\hline 1 & 435 & 60 & 115 \\
2 & 440 & 60 & 143 \\
3 & 450 & 60 & 150 \\
4 & 450 & 20 & 75 \\
\hline
\end{tabular}

temperature range from 82 to $350{ }^{\circ} \mathrm{C}$ for separation of products which are subjected to further analysis and testing, Fig. 2. The fractional distillation was achieved for the hydrocracking product to obtain the different distilled fractions: 1 - bio gasoline $\left(<120{ }^{\circ} \mathrm{C}\right), 2$-bio kerosene $\left(120-245{ }^{\circ} \mathrm{C}\right)$, 3-biodiesel $\left(245-350{ }^{\circ} \mathrm{C}\right), 4-$ heavy product $\left(>350^{\circ} \mathrm{C}\right)$ as shown in Fig. 3 .

\section{Preparation of $\mathrm{GC} /$ mass analytical procedure}

Gas chromatography Mass (GC/MS) was performed for determination of the product fuel constitution using Thermo Scientific, ISQ Single Quadruple MS, TG-5 MS fused silica capillary column $(30 \mathrm{~m}, 0.251 \mathrm{~mm}, 0.1 \mathrm{~mm}$ film thickness). For GC/MS detection, an electron ionization system with ionization energy of $70 \mathrm{eV}$ (electron volt) was used. Helium is used as a carrier gas at a constant flow rate of $1 \mathrm{ml} / \mathrm{min}$. The column oven temperature is initially held at $60{ }^{\circ} \mathrm{C}$ and then increased by $5{ }^{\circ} \mathrm{C} / \mathrm{min}$ to $200{ }^{\circ} \mathrm{C}$ hold $2 \mathrm{~min}$ then increased to $280{ }^{\circ} \mathrm{C}$ $\left(10^{\circ} \mathrm{C} / \mathrm{min}\right)$.
Elemental analysis and high heating value (HHV)

\section{calculation}

Elemental composition of crude oils $(\mathrm{C}, \mathrm{H}, \mathrm{N}, \mathrm{O}, \mathrm{S})$ were determined using Agilent model elemental analyzer (7800 ICP-MS) and HHV was calculated using modified Dulong equation (Bousdira et al. 2014):

$$
\begin{aligned}
\mathrm{HHV}(\mathrm{kJ} / \mathrm{kg})= & 4.18 *(78.4 * \mathrm{C}+241.3 *(\mathrm{H}-\mathrm{O} / 8) \\
& +22.1 * \mathrm{~S})
\end{aligned}
$$

\section{Gas chromatography (GC)}

The profiles of WCO was determined by GC with capillary column DB-5 (60 m: ID $0.33 \mathrm{~mm})$. Helium was used as a carrier gas at flow rate $1 \mathrm{ml} / \mathrm{min}$, column temperature was kept at $240^{\circ} 143 \mathrm{C}$ for $30 \mathrm{~min}$.

\section{Preparation of (10\%) biojet fuel blend testing}

Blend of jet A-1 (kerosene) with $10 \%$ of produced biojet from WCO was subjected to a jet engine test (Jet-Cat 80/120) Fig. 4 and the resulted thrust was compared with that obtained from jet A-1.

\section{Results and discussion}

Physicochemical properties of waste cooking oil

The chemical composition (wt\%) and physical characterization of WCO are given in Table 2 from which it is clear that the composition and properties of $\mathrm{WCO}$ indicated that the fuel produced from the feedstock are regarded as environmentally benign green fuels; the acidity of the oils is within the acceptable range, insuring that oil does not contain any corrosive materials which confirm high quality of oil. The iodine value of WCO was $76 \mathrm{~g}$ of $\mathrm{I}_{2} / 100 \mathrm{~g}$ oil, indicating that the oil contained many unsaturated $\mathrm{C}=\mathrm{C}$ bonds as linoleic acid.

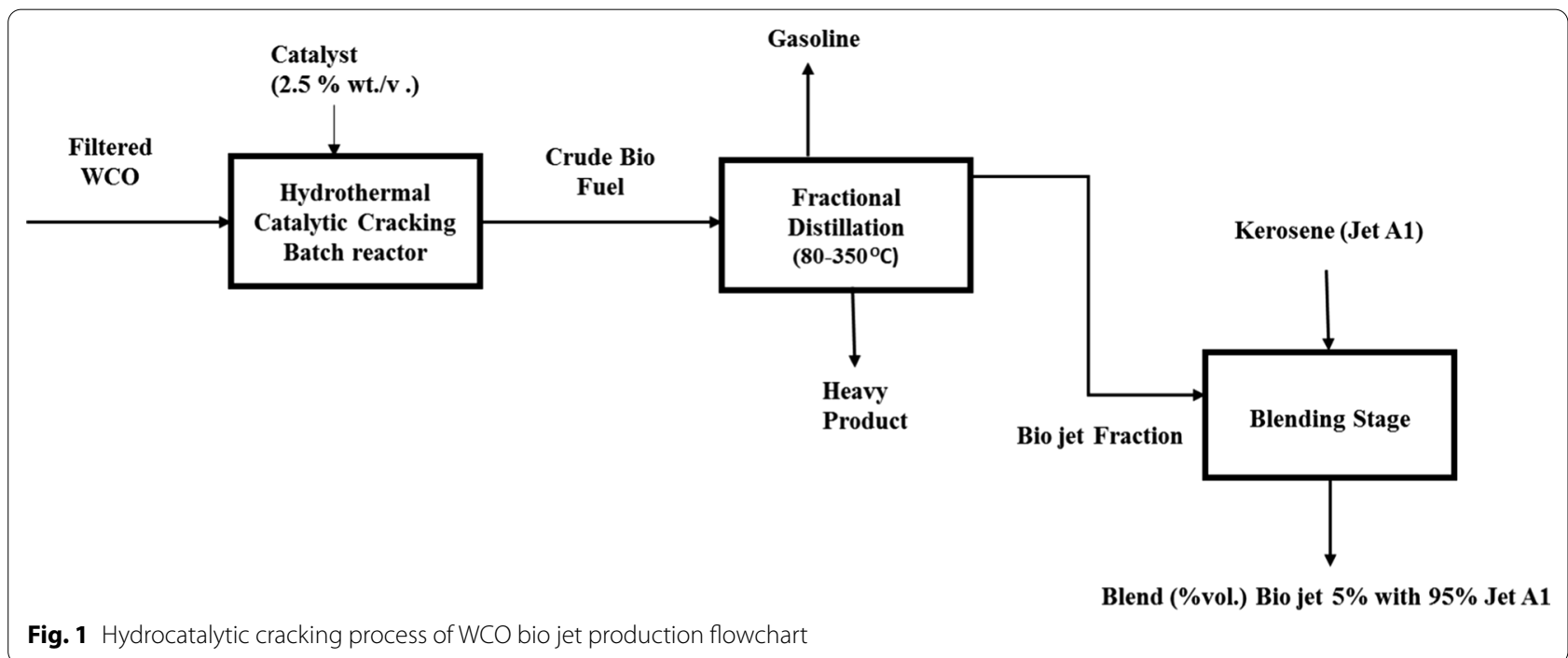



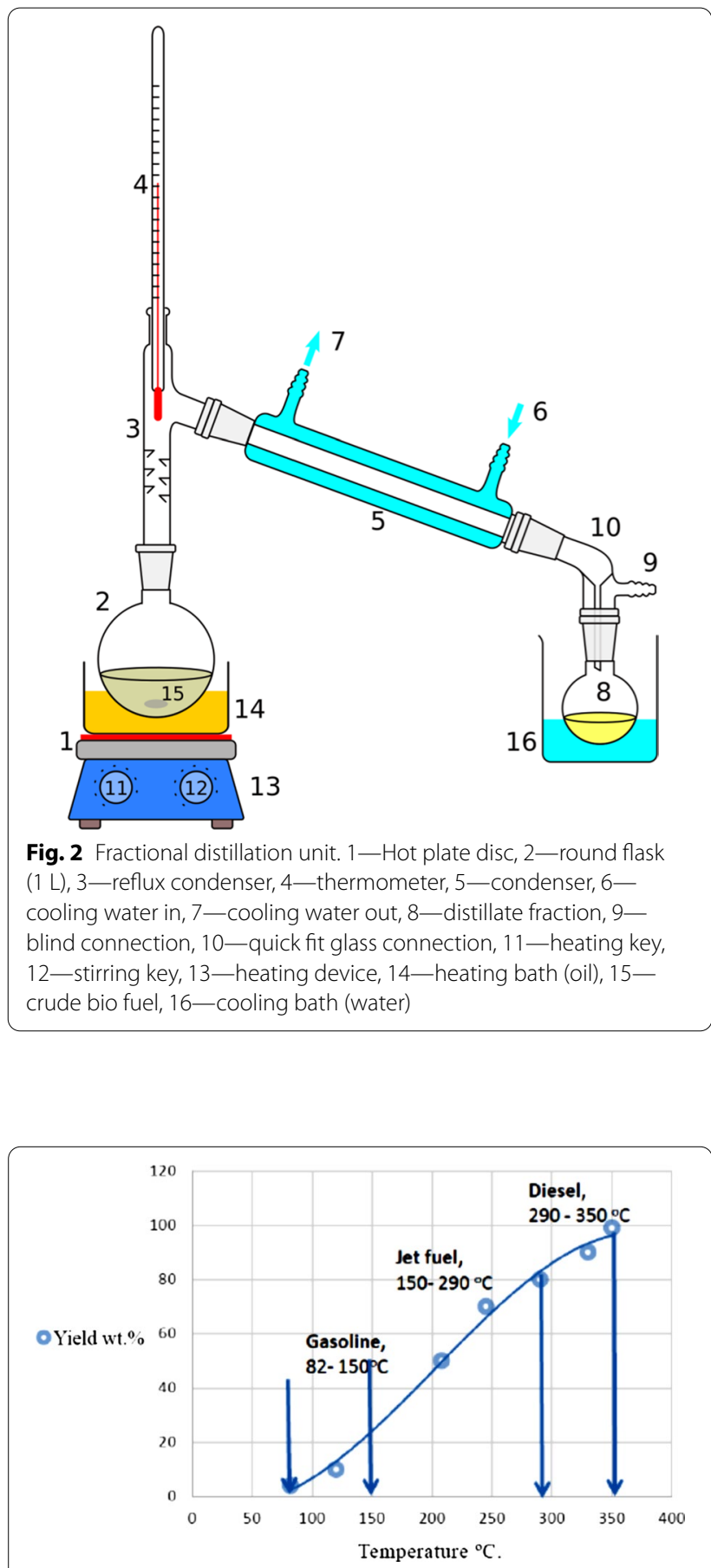

Fig. 3 Distillation fractions via \%yield of the hydro catalytic cracking products

From elemental analysis, oxygen content was small and nitrogen was negligible and no presence of sulfur was detected. Magnitude of $\mathrm{HHV}$ was $13.7 \mathrm{MJ} / \mathrm{kg}$ for WCO as shown in Table 2 which indicated that it is quite good for fuel production.

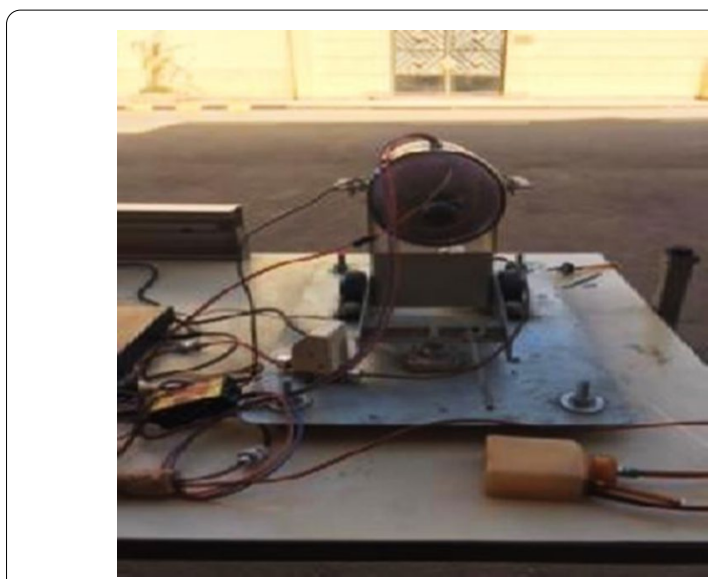

Fig. 4 Jet-Cat 80/120 testing engine

Table 2 Physical characterization and chemical composition of WCO feed stock

\begin{tabular}{|c|c|}
\hline Parameter & $\begin{array}{l}\text { Waste } \\
\text { cooking oil } \\
\text { (WCO) }\end{array}$ \\
\hline Viscosity at $40^{\circ} \mathrm{C} \mathrm{mm} / \mathrm{s}$ & 39 \\
\hline Density $\mathrm{g} / \mathrm{cm}^{3}$ & 0.9 \\
\hline Acidity $\mathrm{KOH} /$ goil & 0.5 \\
\hline lodine value $\mathrm{gl}_{2} / 100 \mathrm{~g}$ & 76 \\
\hline Pour point ${ }^{\circ} \mathrm{C}$ & -9 \\
\hline Cloud point ${ }^{\circ} \mathrm{C}$ & -4 \\
\hline \multicolumn{2}{|l|}{ Elemental analysis } \\
\hline C (wt\%) & 76.8 \\
\hline$H(w t \%)$ & 11.6 \\
\hline $\mathrm{O}(w t \%)$ & 10.6 \\
\hline$N(w t \%)$ & 1 \\
\hline $\mathrm{S}(\mathrm{wt} \%)$ & Nil \\
\hline $\mathrm{HHV}(\mathrm{MJ} / \mathrm{kg})$ & 13.7 \\
\hline$<\mathrm{C} 5(\%)$ & - \\
\hline C5-C7 (\%) & - \\
\hline C8-C16 (\%) & 39.8 \\
\hline C17-C19 (\%) & 60.1 \\
\hline >C19 (\%) & - \\
\hline
\end{tabular}

\section{Catalyst characterization}

In thermal catalytic cracking (TCC) process the type of catalyst is one of the most important factors that affect the composition of the product (Prussi et al. 2019). Zinc Aluminate $\left(\mathrm{ZnAl}_{2} \mathrm{O}_{4}\right)$ is the catalyst in this study due its effectiveness in decreasing $\mathrm{H} / \mathrm{C}$ ratio less than other metallic oxide catalyst (Xu et al. 2016). This indicates that the product of thermal cracked oil via 
Table 3 Physicochemical properties of $\mathrm{ZnAl}_{2} \mathrm{O}_{4}$ catalyst

\begin{tabular}{lll}
\hline BET surface area $\left(\mathbf{m}^{\mathbf{2}} / \mathbf{g}\right)$ & Particle size diameter $(\mathbf{n m})$ & Shape \\
\hline 85 & 7.5 & Sphere
\end{tabular}

$\mathrm{ZnAl}_{2} \mathrm{O}_{4}$ was not only aromatic compound but more saturated alkanes (Hanafi et al. 2015).

$\mathrm{BET}$ surface area and particle size of the used $\mathrm{ZnAl}_{2} \mathrm{O}_{4}$ freshly prepared is shown in Table 3 .

The particle size and morphology of $\mathrm{ZnAL}_{2} \mathrm{O}_{4}$ nano particle were investigated by using transmission electron microscope (TEM). It was noticed that the particle size possess a narrow size distribution and the average particle diameter was about $7.6 \mathrm{~nm}$. The specific surface area measured by the BET method is relatively high $\left(85 \mathrm{~m}^{2} / \mathrm{g}\right)$ which is beneficial due to its catalytic activity. These data are in good agreement with previous work (Weng et al. 2015) where Ni-HZSM-5/SBA-15 catalyst of diameter $8.7 \mathrm{~nm}$ was effective in converting large molecular biomass (sorbitol) into small molecule hydrocarbons so the co-precipitation method confirms that it is the best method for the preparation of $\mathrm{ZnAl}_{2} \mathrm{O}_{4}$ as solid nanoparticles.

The overall process for the preparation of the $\mathrm{ZnAL}_{2} \mathrm{O}_{4}$ from $\mathrm{AL}^{3+}$ and $\mathrm{Zn}{ }^{2+}$ nitrate using ammonium hydroxide is illustrated by the following equation:

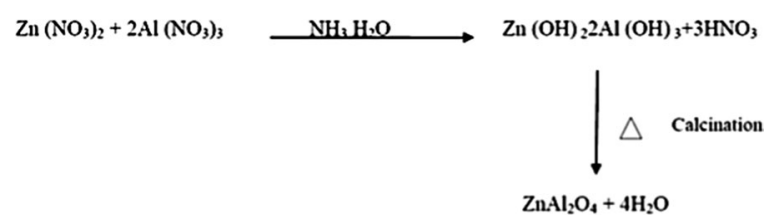

\section{Parameters affecting the thermal catalytic cracking Process Effect of temperature}

Thermal cracking of WCO was investigated at different temperatures from 400 to $450{ }^{\circ} \mathrm{C}$. The products were preliminary evaluated by measuring their freezing points (Oliveira et al. 2018).

High reaction temperature $\left(400-450^{\circ} \mathrm{C}\right)$ was the optimum to crack long chain of oils (tri glycerides $>\mathrm{C} 8-$ C16) to give shorter chain $(\mathrm{C} 8-\mathrm{C} 16)$ which are the main constituents of bio aviation to assure reaching properties in a good agreement compared to those of petroleum-based jet fuel.

By measuring freezing point, it was found that increasing the reaction temperature improves the freezing point of the product Table 4.
Table 4 Effect of reaction temperature on product freezing points (reaction time: $60 \mathrm{~min}$, catalyst $2.5 \% \mathrm{wt}$ / vol and 120 bar)

\begin{tabular}{ll}
\hline Reaction temperature $\left({ }^{\circ} \mathrm{C}\right)$ & $\begin{array}{l}\text { Biofuel product } \\
\text { freezing point } \\
\left({ }^{\circ} \mathbf{C}\right)\end{array}$ \\
\hline 400 & -48 \\
430 & -49 \\
450 & -52 \\
\hline
\end{tabular}

\section{Effect of reaction time}

The results showed a linear relationship between time and freezing point Fig. 5, where the freezing point reached its lower value after $(60 \mathrm{~min})$ reaction time. The freezing points of the products was considered as a good indication of the reactant conversion to the biojet fuel, the reaction can be represented by the Eq. (a) which are linear relationships between freezing point (Fp.) and time $(t)$ for WCO hydro catalytic cracking.

$$
\mathrm{Fp} .=0.46 t+40.1
$$

From the previous data, it can be concluded that the acceptable freezing points for fuel product are obtained within $60 \mathrm{~min}$. This result gave a promising potential in the bio aviation manufacture starting from WCO due to economic and environmental purposes, being of lower cost than vegetable oils and environmentally positive way for using oil wastes.

\section{Results of the distillation steps}

Fractions obtained from distillation procedure are shown in Fig. 3 which illustrated that the bio gasoline product was collected up to $150{ }^{\circ} \mathrm{C}$ while biojet fuel range was obtained from 150 to $290{ }^{\circ} \mathrm{C}$ then finally bio diesel fuel was produced from 290 to $350^{\circ} \mathrm{C}$.

Thermal cracking of WCO under optimum conditions gave about $96 \%$ crude bio fuel. After the distillation step of crude bio fuel, about $49 \%$ of bio aviation fraction was obtained and the rest (51\%) were biodiesel and heavy fuel with calorific values suitable as bio fuel to be used in other purposes. These results are in good agreement with ASTM standards (Dai et al. 2018).

\section{$\mathrm{GC} /$ mass spectra results}

The formation of alkanes, cycloalkanes, iso alkanes and alkyl benzene during thermal catalytic cracking of WCO was investigated by $\mathrm{GC} /$ mass to classify hydrocarbons present in the product feedstock. The results showed that: the hydrocarbon mixture contained n-paraffin, iso 


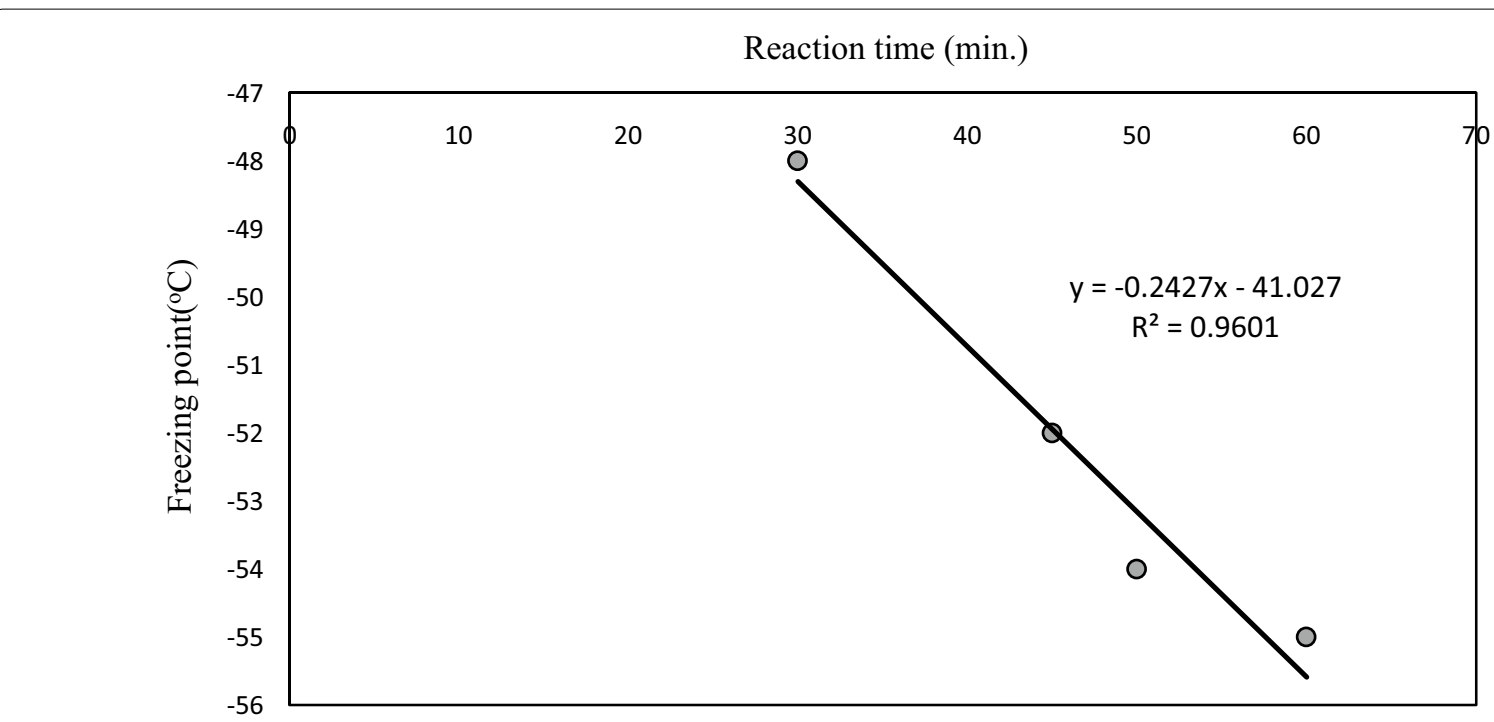

Fig. 5 The effect of reaction time on freezing point of bio fuel product from WCO hydro catalytic cracking

ఐOlefines $\quad$ Iso-Paraffin $\quad$ n-Paraffin $\quad$ CyclParaffin $\quad$ Others

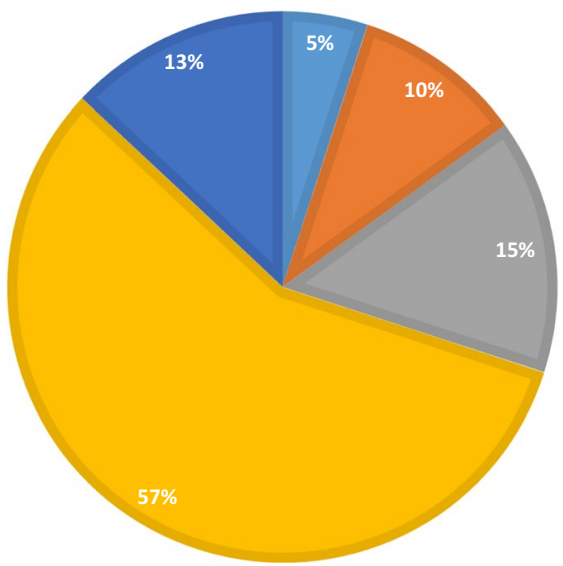

Fig. 6 GC Mass \% of different hydrocarbons in carbon length $C_{8}-C_{16}$ of WCO bio aviation fuel

paraffin, cyclo paraffin, olefins and aromatics. It can be confirmed that typical ideal carbon length of $\mathrm{C}_{8}-\mathrm{C}_{16}$ in jet fuel is from 70 to $85 \%$. Total yield of paraffin content in bio aviation fuel obtained was close to $83 \%$ as shown from Fig. 6.

GC-mass spectra data illustrated that most of iso and cyclo-paraffins have one /two branched chain of alkanes, as methyldecane, alkyl cyclohexane and iso octane (2,2,4-trimethylpentane) in the total product. This is in agreement with the literature (57.01\%) (Holladay 2015b).

It is interesting to say that the obtained unrequired olefins is near about minimum (5\% wt\%) as in ideal jet
Table 5 Specifications of jetA1 blended with $5 \%$ of biojet range distillate

\begin{tabular}{llll}
\hline Properties & Results & Specification limits & Test method \\
\hline $\begin{array}{l}\text { Flash point }{ }^{\circ} \mathrm{C} \\
\text { Density @ } 15^{\circ} \mathrm{C} \mathrm{kg} / \mathrm{m}^{3}\end{array}$ & $\begin{array}{l}71.5 \\
798.4\end{array}$ & $\begin{array}{c}38 \text { (min.) } \\
775 \text { (min.) to } 840 \\
(\text { max. }\end{array}$ & IP 170 \\
$\begin{array}{l}\text { Copper corrosion, } \\
\text { rating }\end{array}$ & 1 & 1 (max.) & ASTM D-4052 \\
$\begin{array}{l}\text { Existent gum } \\
\text { mg } / 100 \mathrm{ml}\end{array}$ & 1.6 & 7 (max.) & ASTM D-130 \\
\begin{tabular}{l} 
Freezing point ${ }^{\circ} \mathrm{C}$ \\
\hline
\end{tabular} & -55 & -43 (min.) & ASTM-381 \\
\hline
\end{tabular}

fuel. Also GC/mass spectra data illustrated that most of iso, cyclo-paraffin have one or two branches as methyldecane, and straight chain alkanes or branched chain cycloalkane as iso octane.

Molecules as methyldecane (iso-paraffin) are much more represented in petroleum jet fuel component than iso-octane (branched alkane). Jet fuel range iso-paraffin is the most expensive and difficult component to obtain, was detected in good ratio in the prepared bio aviation fuel.

Pure fuel is highly dependent on the amount of branched alkanes because increase in branching suppresses the fuel ignition point (Eldeeb 2007).

\section{Biojet blend (10\%) test}

Specifications of $5 \%$ blend of biojet from WCO are illustrated in Table 5 and compared with the standards specifications results were within the required limit. The test proved that the obtained thrust of using $5 \%$ blend is in 


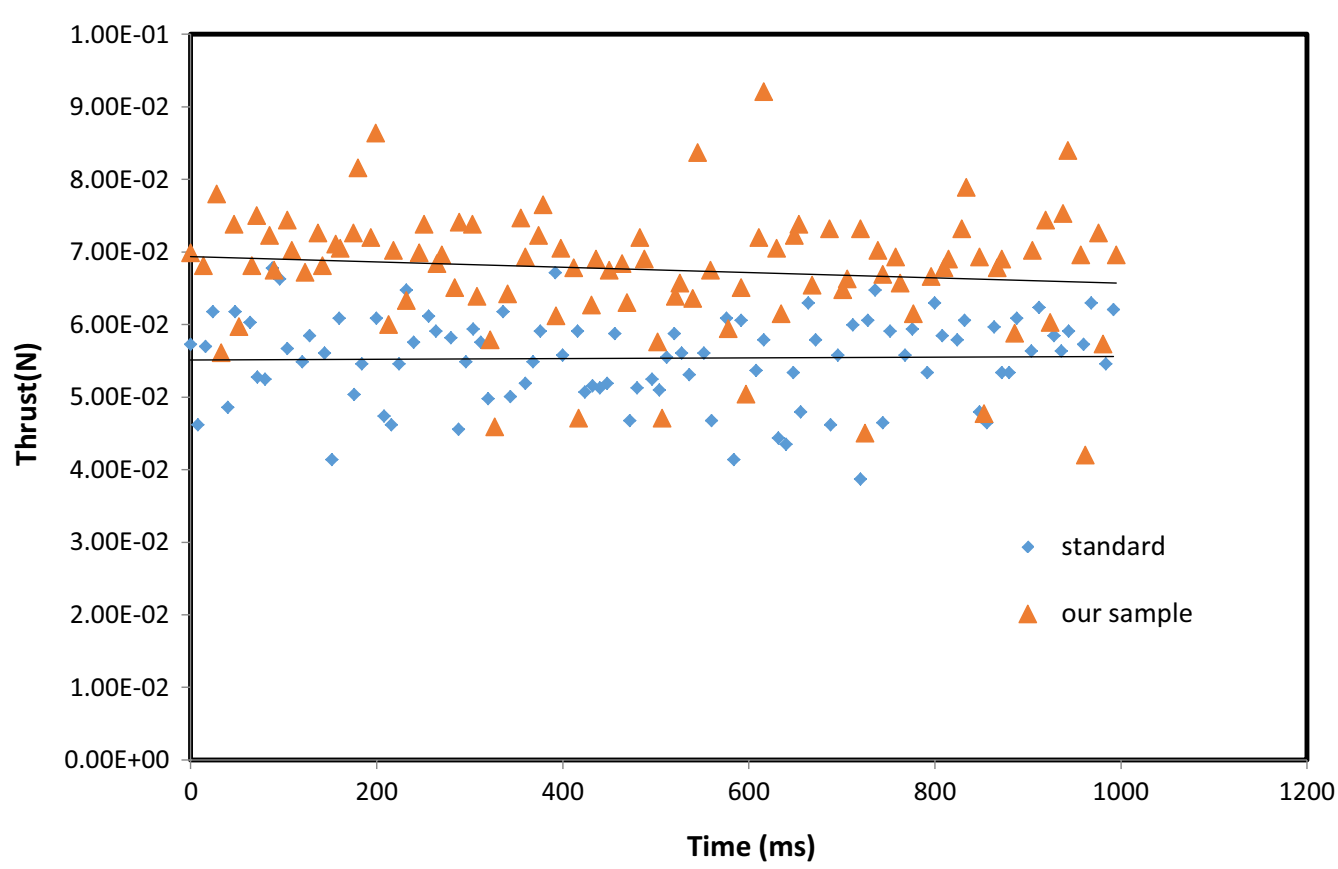

Fig. 7 Thrust test results for blend bio jet

a good agreement with jet A-1. Figure 7. Blue points are different thrust values of the petroleum jet fuel (kerosene jet fuel) where red points are different thrust of the blend kerosene jet fuel and $5 \%$ biojet obtained in this work at different time during the testing experiment and it shows the higher thrust values of blend biojet than the pure petroleum kerosene.

The submitting of biofuels into aviation sector must not alter the aircraft engine performance and the fuel must keep its properties during the wide range of atmospheric conditions during flights (ASTM International 2015).

\section{Conclusions}

From the study it is concluded that:

- Renewable bio aviation fuel can be produced via thermal catalytic cracking of vegetable oils where conversion of WCO to hydrocarbon range alkanes has been successfully performed under high temperature and pressure.

- Biojet fuel obtained from WCO has fairly acceptable physico-chemical properties compared to those of petroleum based fuel.

- Adjustment of the hydro catalytic cracking reaction conditions was used to control quantities and characteristics of produced bio aviation fuel.

- Results of this study revealed that hydrothermal catalytic cracking of WCO gave convenient freezing point $\left(-55^{\circ} \mathrm{C}\right)$ for use as biojet fuel.
- Taking into consideration the economic evaluation WCO is preferable as raw material for bio aviation fuel production due to its low cost and its contribution in environmental pollution abatement.

- Bio aviation fuel fraction from $\left(\mathrm{C}_{8}-\mathrm{C}_{16}\right)$ was obtained by fractional distillation of hydrocracking product from temperature from 120 to $250^{\circ} \mathrm{C}$.

- Blend of 5\% bio aviation with jet A-1 (by volume) can be used in the engine without any modifications and a successful test of blended bio aviation fuel with $10 \%$ bio aviation has been achieved on Jet-Cat 80/120 engine.

Abbreviations

WCO: Waste cooking oil; IATA: International Air Transport Association; GHG: Greenhouse gas; FAME: Fatty acid methyl esters; ASTM: American Society for Testing and Materials; HBBA: High biofuel blends in aviation; BET: BrunauerEmmett-Teller; TEM: Transmission electron microscope.

Acknowledgements

Not applicable.

\section{Authors' contributions}

$R E$, EA, Sl: experimental part and writing the research paper. SI, GE, RE, EA: preparing experiments work plan. GE: reviewing and contributing in writing the research paper. All authors have read and approved the manuscript.

\section{Funding}

The authors declare that they have no known competing financial interests or personal relationships that could have appeared to influence the work reported in this paper.

Availability of data and materials

Data sharing is not applicable to this article as no datasets were generated or analyzed during the current study. 
Ethics approval and consent to participate

There is no committee of approval.

\section{Consent for publication}

Not applicable.

\section{Competing interests}

The authors declare that they have no competing interests.

Received: 12 August 2020 Accepted: 20 September 2020

Published online: 12 October 2020

\section{References}

ASTM International (2015) ASTM D1655-15de1. Standard specification for aviation turbine fuel. https://doi.org/10.1520/D1655-15DE01

Bailis RE, Bake JE (2010) Greenhouse gas emissions and land use change from Jatropha-curcas based jet fuel in Brazil. Environ Sci Technol 44(22):8684-8691

Battiston S, Rigo C, Severo EDC, Mazutti MA, Kuhn RC, Gündel A, Foletto EL (2014) Synthesis of zinc aluminate $\left(\mathrm{ZnAl}_{2} \mathrm{O}_{4}\right)$ spinel and its application as photocatalyst. Mater Res 17(3):734-738

Blakeley K (2012) DOD alternative fuels: policy, initiatives and legislative activity. Congressional Research Service

Bousdira K, Nouri L, Legrand J, Bafouloulou Y, Abismail M, Chekhar H, Babahani M (2014) A nove rview of the chemical composition of phoenicicol biomass fuel in Guerraraoasis. Revue des Energies Renouvel ables SIENR'14 Ghardaïa, pp 99-108

Briefing. Long-term aviation fuel de carbonization: progress, roadblocks, and policy opportunities. ICCT, 2019

Chairamonti D (2019) Sustainable aviation fuels: the challenge of decarbonization. Energy Procedia 158:1202-1207

Chuck CJ, Donnelly J (2014) The compatibility of potential bioderived fuels with Jet A-1 aviation kerosene. Appl Energy 118:83-91

Corporan E, Edwards T, Shafer L, DeWitt MJ, Klingshirn C, Zabarnick S et al (2011) Chemical, thermal stability, seals well, and emissions studies of alternative jet fuels. Energy Fuels 25(3):955-966

Dai Q, Zhang Z, Zhan T, Hu Z-T, Chen J (2018) Catalytic ozonation for the degradation of 5-sulfosalicylic acid with spinel-type $\mathrm{ZnAl}_{2} \mathrm{O}_{4}$ prepared by hydrothermal, sol-gel, and co precipitation methods: a comparison study. ACS Omega 3:6506-6512

De Oliveira VF, Parente EJS, Cavalcante CL, Luna FMT (2018) Short-chain esters enriched biofuel obtained from vegetable oil using molecular distillation. Can J Chem Eng 96:1071-1078

El Diwani G, Hawash SI, Kamal N (2009) Development and evaluation of biodiesel fuel and byproducts from Jatropha oil. IJEST Int J Environ Sci Technol 6:219-224

Eldeeb M (2007) Characterization and chemical kinetic analysis of the ignition of representative conventional and bio-derived fuels representative conventional and bio-derive. In: 45th AIAA, aerospace sciences meeting and exhibit, Reno, Nevada

Gawron B, Białecki T (2018) Impact of a Jet A-1/HEFA blend on the performance and emission characteristics of a miniature turbojet engine. Int J Environ Sci Technol 15(7):1501-1508

Hanafi SA, Elmelawy MS, El-Syed HA, Shalaby NH (2015) Hydrocracking of waste cooking oil as renewable fuel on $\mathrm{NiW} / \mathrm{SiO} 2-\mathrm{Al}_{2} \mathrm{O}_{3}$ catalyst. J Adv Catal Sci Technol 2:27-37

Hawash SI, Abdelkader E, Amin A, El-Araby R, El Diwani G (2017) Investigation of metallic oxide catalyst role for upgrading biodiesel to bio jet fuel range hydrocarbon. ARPN J Eng Appl Sci 12(7):387-388

Hileman JI, Stratton RW (2014) Alternative jet fuel feasibility. J Transport Policy $34: 52-62$
Holladay J (2015a) Jet fuel advances in bio-oil and alcohol upgrading. In: Sustainable alternative aviation fuels workshop, 106, 313

Holladay J (2015b) Sustainable alternative aviation fuels workshop. CORE-JetFuel

Howe D, Westover T, Carpenter D, Santosa D, Emerson R, Deutch S et al (2015) Field-to-fuel performance testing of lignocellulosic feedstocks: an integrated study of the fast pyrolysis382 hydrotreating pathway. Energy Fuels 29(5):3188-3197

Mante OD, Butcher TA, Wei G, Trojanowski R, Sanchez V (2017) Evaluation of biomass-derived distillate fuel as renewable heating oil. BNL-114132-JA

Pires APP, Han Y, Kramlich J, Garcia-Perez M (2018) Chemical composition and fuel properties of alternative jet fuels. BioResources 13(2):2632-2657

Prussi M, O'Connell A, Lonza L (2019) Analysis of current aviation biofuel technical production potential in EU28. Biomass Bioenergy 130:105371

Sathaye J, Lucon O, Rahman A, Christensen J, Denton F, Fujino J et al (2011) Renewable energy in the context of sustainable development. Special report on renewable energy sources and climate change mitigation. Cambridge University Press, Cambridge

Skreiberg O, Grønli MG, Antal MJ Jr (2013) The smart biofuels of the future. Biofuels 4(2):159-161

Staplesa MD, Malina R, Suresha P, Hileman JI, Barretta SRH (2018) Aviation CO emissions reductions from the use of alternative jet fuels. Energy Policy 114:342-354

Sun $X$ (2012) Forensic applications of gas chromatography/mass spectrometry, high performance liquid chromatography-mass spectrometry and desorption electrospray ionization mass spectrometry with chemo metric analysis of aviation jet fuel. A dissertation Faculty of the College of Arts and Sciences of Ohio University

Sustainable Aviation Fuels Northwest Project: www.climatesolutions.org/progr ams/aviation-biofuels-initiative

Talmadge MS, Baldwin RM, Biddy MJ, McCormick RL, Beckham GT, Ferguson GA et al (2014) A perspective on oxygenated species in the refinery integration of pyrolysis oil. Green Chem 16(2):407-453

Tao L, Milbrandt A, Zhang Y, Wang WC (2017) Techno-economic and resource analysis of hydroprocessed renewable jet fuel. Biotechnol Biofuels 10:261

Wahyudi ING et al (2018) Improving vegetable oil properties by transforming fatty acid chain length in jatropha oil and coconut oil blends. Energies 11:394

Wang W-C, Tao L (2016) Bio-jet fuel conversion technologies. Renew Sustain Energy Rev 53:801-822

Wang W-C, Tao L, Markham J, Zhang Y, Tan E, Batan L, Warner E, Biddy M (2016) Review of biojet fuel conversion technologies. Technical Report, NREL/ TP-5100-66291, National Renewable Energy Laboratory, 2016

Weng Y, Qiu S, Ma L, Liu Q, Ding M, Zhang Q (2015) Biomass-derived sorbitol over Ni-HZSM-5/SBA-15 catalyst. Catalyst 5:2147-2160

Xu J, Jiang J, Zhao J (2016) Thermo chemical conversion of triglycerides for production of drop-in liquid fuels. Renew Sustain Energy Rev 58:331-340

Yang J, Xin Z, He Q, Corscadden K, Niu H (2019) An overview on performance characteristics of bio-jet fuels. Fuel 237:916-936

Zacher AH, Olarte MV, Santosa DM, Elliott DC, Jones SB (2014) A review and perspective of recent bio-oil hydrotreating research. Green Chem 16(2):491-515

Zacher AH, Elliott DC, Olarte MV, Santosa DM, Preto F, lisa K (2014) Pyrolysis of woody residue feedstocks: hydro thermal cracking of bio-oils from mountain-pine-beetle killed trees and hog fuel. Energy Fuels 28(12):7510-7516

\section{Publisher's Note}

Springer Nature remains neutral with regard to jurisdictional claims in published maps and institutional affiliations. 